\title{
Sequence of a Cloned pR72H Fragment and Its Use for Detection of Vibrio parahaemolyticus in Shellfish with the PCR
}

\author{
CHIA-YIN LEE, * SHWU-FEN PAN, AND CHIEN-HSIEN CHEN \\ Graduate Institute of Agricultural Chemistry, National Taiwan University, \\ Taipei, Taiwan 10764, Republic of China
}

Received 6 September 1994/Accepted 2 February 1995

\begin{abstract}
The nucleotide sequence of pR72H cloned from Vibrio parahaemolyticus 93 was determined. We examined all $V$. parahaemolyticus gene sequences published in the GenBank-EMBL databases for homology and found that no other DNA sequence of $V$. parahaemolyticus was highly homologous to the sequence reported in this study. A pair of primers, VP33-VP32, derived from a $\mathrm{pR72H}$ fragment were selected to detect $V$. parahaemolyticus. The sensitivity of PCR detection for a pure culture of $V$. parahaemolyticus was 10 cells from crude bacterial lysates. Furthermore, a detection level of $2.6 \mathrm{fg}$, equivalent to 1 cell, was obtained by using purified chromosomal DNA as the template. The expected PCR products were obtained from all $V$. parahaemolyticus strains tested $(n=$ 124), while no PCR amplicons were found in other vibrios or related genera $(n=50)$. High levels $\left(10^{6}\right.$ to $10^{10}$ $\mathrm{CFU} / \mathrm{ml}$ ) of Escherichia coli cells did not affect the PCR assay sensitivity. The presence of $10^{8} \mathrm{~V}$. parahaemolyticus cells or $10^{9} \mathrm{E}$. coli cells in the PCR mixtures completely inhibited the PCR. When oyster samples were inoculated with $V$. parahaemolyticus 93 and cultured in tryptic soy broth containing $3 \% \mathrm{NaCl}$ for $3 \mathrm{~h}$ at $35^{\circ} \mathrm{C}$, an initial sample inoculum level of $9.3 \mathrm{CFU} / \mathrm{g}$ was detected in a PCR assay with crude bacterial lysates. The PCR assay with enrichment culturing in salt polymyxin broth was compared with the conventional method for naturally contaminated shellfish and fish samples. We conclude that this PCR assay with enrichment culturing is a good alternative method for the detection of $V$. parahaemolyticus.
\end{abstract}

Vibrio parahaemolyticus is an enteric pathogen, and shellfish contaminated with this pathogen have been a source of disease outbreaks in Taiwan, Japan, and other coastal regions $(5,22$, $25)$. A lethal toxin $(20,41)$ and a vascular permeability factor (19), as well as thermostable direct hemolysin (44) and other related hemolysins $(18,33,35)$, have been identified in $V$. parahaemolyticus. The incidence of $V$. parahaemolyticus in the environment and shellfish varies greatly, depending on the season, location, sample type, level of fecal pollution, and analytical method $(3,8,9,48)$. An accurate and rapid method for identifying food products contaminated with $V$. parahaemolyticus would aid in the prevention of such outbreaks. Recently, a sensitive and rapid technique, PCR, has been used to identify the presence of $t d h$ (thermostable direct hemolysin) and/or trh (thermostable direct hemolysin-related hemolysin) genes in $V$. parahaemolyticus $(29,30,43)$. We have reported the development of a PCR technique which can specifically detect hemolysin genes $(t d h)$ in strains of hemolytic $V$. parahaemolyticus associated with human gastroenteritis and have applied it successfully to stool specimens from outbreak patients $(29,30)$. The oligonucleotide primers used in the previously reported PCR procedure were derived from the nucleotide sequence of the $t d h$ gene of $V$. parahaemolyticus $(29,30)$.

However, few environmental or seafood isolates of $V$. parahaemolyticus produce thermostable direct hemolysin as most cases of gastroenteritis associated with clinical isolates do (9, 33). Dai et al. (7) demonstrated that an environmental nonhemolytic strain of $V$. parahaemolyticus, CCRC12958, also exhibited lethality for mice in iron-limited cultures, which is similar

\footnotetext{
* Corresponding author. Mailing address: Graduate Institute of Agricultural Chemistry, National Taiwan University, 1, Sec. 4, Roosevelt Rd., Taipei, Taiwan 10764, Republic of China. Phone: 886-2-3630231, ext. 2816. Fax: 886-2-3660581.
}

to the responses of clinical strains. They concluded that hemolysin or thermostable direct hemolysin may not be the sole major lethal factor for mice and that another toxic factor or factors lethal for mice may be present in CCRC12958. Yoh et al. (52) also demonstrated that Kanagawa phenomenon-negative environmental strains of $V$. parahaemolyticus can produce thermostable direct hemolysin-related hemolysin which is physiochemically, biologically, and immunologically indistinguishable from the toxin from clinical isolates. That Kanagawanegative $V$. parahaemolyticus is associated with wound infection and gastroenteritis has been well documented (21, 23, 25, 38 ). These reports have suggested that a certain percentage of environmental strains of $V$. parahaemolyticus are responsible for pathogenesis.

We are interested in developing a PCR protocol specific to $V$. parahaemolyticus from food or environmental isolates, which could be useful for epidemiological surveys, determination of distribution and source, identification, and routine monitoring of this bacterium in contaminated shellfish and other seafood. In a previous study, we cloned a 0.76-kb HindIII DNA fragment of the chromosomal DNA of $V$. parahaemolyticus 93 into pUC119. This cloned DNA fragment, designated pR72H, can be used as a species-specific DNA probe for $V$. parahaemolyticus. Although the function of this DNA fragment is still unknown, the pR72H DNA fragment is conservative in all strains of $V$. parahaemolyticus tested (28). In the present study, we determined the sequence of $\mathrm{pR} 72 \mathrm{H}$ and developed a successful approach for detection of $V$. parahaemolyticus in shellfish by using enrichment culturing with a PCR assay.

\section{MATERIALS AND METHODS}

Bacterial strains and culture media. The $V$. parahaemolyticus isolates, other vibrios, and strains from other genera used in this study to evaluate specificity and sensitivity and their sources are listed in Table 1. Tryptic soy agar (TSA) 
TABLE 1. Bacterial strains used in this study

\begin{tabular}{|c|c|c|}
\hline Species & $\begin{array}{l}\text { No. of } \\
\text { strains }\end{array}$ & Source $(\mathrm{s})^{a}$ \\
\hline \multirow[t]{5}{*}{ Vibrio parahaemolyticus } & 4 & ATCC \\
\hline & 16 & CCRC \\
\hline & 3 & M. Nishibuchi \\
\hline & 36 & $\begin{array}{l}\text { Clinical isolates from } \\
\text { NIPM, NLFD, } \\
\text { PTPI, and TSGH }\end{array}$ \\
\hline & 65 & $\begin{array}{l}\text { Food isolates from } \\
\text { NIPM, NLFD, } \\
\text { PTPI, and TSGH }\end{array}$ \\
\hline \multicolumn{3}{|l|}{ Other vibrios } \\
\hline Vibrio alginolyticus & 8 & ATCC, K. Aoki \\
\hline Vibrio campbellii & 1 & ATCC \\
\hline Vibrio cholerae & 17 & PTPI \\
\hline Vibrio cholerae non-O1 & 1 & H. C. Wong \\
\hline Vibrio costicola & 1 & ATCC \\
\hline Vibrio damsela & 2 & \\
\hline Vibrio diazotrophicus & 1 & ATCC \\
\hline Vibrio hollisae & 1 & NIPM \\
\hline Vibrio logei & 1 & ATCC \\
\hline Vibrio mimicus & 1 & \\
\hline Vibrio natriegens & 1 & ATCC \\
\hline Vibrio pelagius & 1 & ATCC \\
\hline Vibrio percolans & 1 & IFO \\
\hline Vibrio vulnificus & 1 & ATCC \\
\hline \multicolumn{3}{|l|}{ Other genera } \\
\hline Aeromonas hydrophila & 2 & CCRC \\
\hline Escherichia coli & 2 & IAM, CCRC \\
\hline Klebsiella pneumoniae & 1 & ATCC \\
\hline Micrococcus luteus & 1 & ATCC \\
\hline Proteus mirabilis & 1 & CCRC \\
\hline Pseudomonas aeruginosa & 2 & \\
\hline Salmonella typhi & 1 & ATCC \\
\hline Salmonella typhimurium & 1 & \\
\hline Staphylococcus aureus & 1 & ATCC \\
\hline
\end{tabular}

${ }^{a}$ Abbreviations: ATCC, American Type Culture Collection, Rockville, Md.; CCRC, Culture Collection and Research Center, Hsinchu, Taiwan; NIPM, National Institute of Preventive Medicine, Taipei, Taiwan; NLFD, National Laboratories of Foods and Drugs, Taipei, Taiwan; PTPI, National Ping-Tung College of Agriculture, Ping-Tung, Taiwan; TSGH, Tri-Service General Hospital, Taipei, Taiwan; IFO, Institute for Fermentation, Osaka, Japan; IAM, Institute of Applied Microbiology, University of Tokyo, Tokyo, Japan.

(Difco) or tryptic soy broth (TSB) (Difco) supplemented with $2.5 \% \mathrm{NaCl}$ was used for growth of all of the Vibrio species. Other bacterial cultures were grown on TSA or TSB medium.

DNA sequence determination. Plasmid pR72 is a pUC119 derivative containing a $0.76-\mathrm{kb}$ HindIII insert of $V$. parahaemolyticus 93 , and the insert DNA fragment is designated pR72H (28). Large-scale plasmid preparation and purification were performed by a modified alkaline lysis procedure and polyethylene glycol precipitation protocol (39). The complete nucleotide sequence of both strands of the insert was determined by a modified dideoxy sequencing method $(31,40)$ with the Sequenase system (United States Biochemical Corp., Cleveland, Ohio). The nucleotide sequence data were analyzed for homology to the published sequences in EMBL or GenBank databases by using the GENALIGN multiple sequence alignment program from IntelliGenetics (IntelliGenetics Corp., Palo Alto, Calif.), which is based on the homology search method of Wilbur and Lipman (51).

Synthetic oligonucleotide primers. Three oligonucleotide primers (22- or 24mer) were designed and synthesized (Bio-Synthesis, Lewisville, Tex.) according to the determined DNA sequence of $\mathrm{pR} 72 \mathrm{H}$, the HindIII insert of $V$. parahaemolyticus used in this study. The sequences were 5'-TGCGAATTCGATAGG GTGTTAACC-3' (designated VP33) and 5'-CGAATCCTTGAACATACGCA GC-3' (designated VP32) as primers and 5'-GGATTGAAACTAGGCTCACTC TCG-3' (designated VP35) as an internal probe. The $T_{m}$ values of the primers and probe were $71.3,69.3$, and $68.4^{\circ} \mathrm{C}$, respectively. The homologous sites for hybridization to the pR72H are shown in Fig. 1.

PCR amplification. The PCR solution contained $1 \times$ PCR amplification buffer $(50 \mathrm{mM} \mathrm{KCl}, 10 \mathrm{mM}$ Tris- $\mathrm{HCl}, 0.1 \%$ Triton X-100), $1.5 \mathrm{mM} \mathrm{MgCl} 2,200 \mu \mathrm{M}$ (each) deoxynucleoside triphosphates, $1 \mu \mathrm{M}$ (each) primers, $1.25 \mathrm{U}$ of Taq DNA

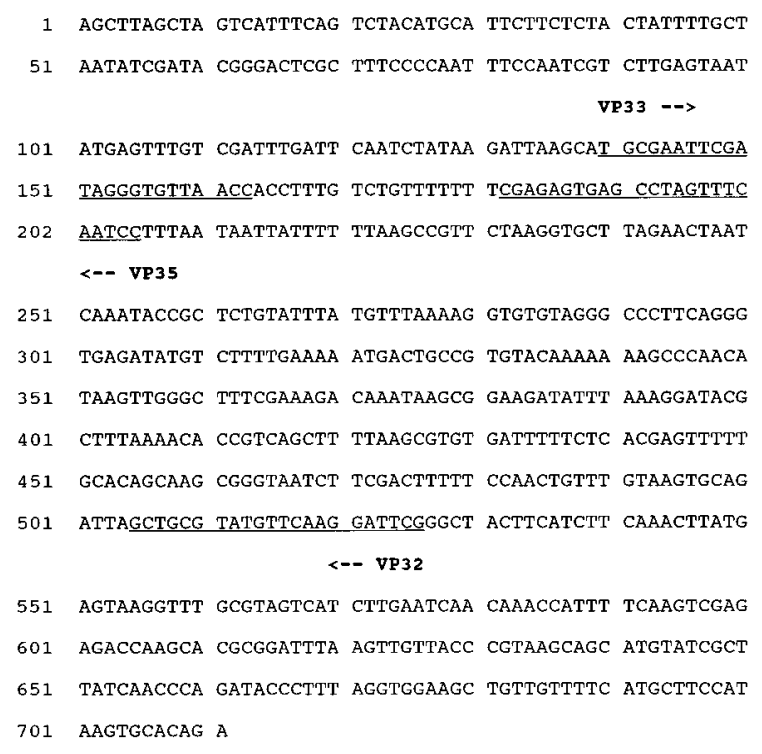

FIG. 1. Nucleotide sequence of $\mathrm{pR} 72 \mathrm{H}$. Underlining indicates the relative positions of oligonucleotides VP33, VP35, and VP32, and dashed arrows show the $5^{\prime}$-to-3' orientations.

polymerase (Promega), $5 \mu \mathrm{l}$ (40 ng) of template DNA or lysed bacterial broth, and double-distilled water treated with $0.1 \%$ diethylpyrocarbonate to make a final volume of $50 \mu \mathrm{l}$. The mixtures were overlaid with $50 \mu \mathrm{l}$ of mineral oil (Sigma) and subjected to 35 PCR cycles in a programmable temperature cycler (ASTEC PC-700, Tokyo, Japan). The parameters for the amplification cycles were denaturation for $1 \mathrm{~min}$ at $94^{\circ} \mathrm{C}$, annealing of primers for $1 \mathrm{~min}$ at $60^{\circ} \mathrm{C}$, and primer extension for $1 \mathrm{~min}$ at $72^{\circ} \mathrm{C}$. After the last cycle, the PCR mixtures were incubated for $10 \mathrm{~min}$ at $72^{\circ} \mathrm{C}$

Detection of PCR products. PCR-amplified DNAs were detected by agarose gel electrophoresis in $2 \%$ agarose gels (Clontec). Ten microliters each of the amplification mixtures and molecular weight markers (pBR322 digest of HinfI DNA) was subjected to electrophoresis and ethidium bromide staining. The specific amplified DNA fragments were visualized by UV illumination.

Southern and dot blot hybridization. For confirmation of the amplified DNA by Southern blot hybridization, $10 \mu \mathrm{l}$ of PCR products was subjected to $2 \%$ agarose gel electrophoresis and then transferred to a Zeta-probe membrane (Bio-Rad) by alkaline Southern blotting (36). An internal oligonucleotide probe (VP35) was labeled with $\left[\gamma_{-}{ }^{32} \mathrm{P}\right] \mathrm{ATP}$ by $5^{\prime}$ end labeling with T4 polynucleotide kinase (Bethesda Research Laboratories) as a probe $\left(10^{6} \mathrm{cpm} / \mathrm{ml}\right)$. The membranes were air dried and hybridized at $40^{\circ} \mathrm{C}$ overnight in $1.5 \times$ SSPE $(1 \times$ SSPE is $0.18 \mathrm{M} \mathrm{NaCl}, 0.01 \mathrm{M}$ sodium phosphate, $0.01 \mathrm{M}$ disodium EDTA), $1 \%$ sodium dodecyl sulfate (SDS), $0.5 \%$ BLOTTO (nonfat dry milk; Carnation), and $0.5 \mathrm{mg}$ of denatured herring sperm DNA per ml (Boehringer Mannheim). After hybridization, the membranes were rinsed with $2 \times$ SSPE and $2 \times$ SSPE $-0.1 \%$ SDS, followed by $0.5 \times \mathrm{SSPE}-0.1 \%$ SDS and $0.1 \times \mathrm{SSPE}-0.1 \%$ SDS, at $25^{\circ} \mathrm{C}$ for 15 $\mathrm{min}$. The last wash was done in $0.1 \times \mathrm{SSPE}-1 \%$ SDS at $40^{\circ} \mathrm{C}$ for $30 \mathrm{~min}$, followed by rinsing with $0.1 \times$ SSPE. After the hybridization, the colony blot or dot blot membranes were autoradiographed with X-Omat film (Eastman Kodak) with intensifying screens and exposure at $-80^{\circ} \mathrm{C}$ for an appropriate length of time.

For confirmation of the PCR products by dot blot hybridization, PCR products were heated at $100^{\circ} \mathrm{C}$ for $10 \mathrm{~min}$ and then loaded on a Zeta-probe membrane with a Bio-Dot microfiltration apparatus (Bio-Rad). The membrane was air dried and stored in a plastic bag until used. Dot blot hybridization followed the same procedure as Southern blot hybridization.

Preparation of artificially contaminated oysters. Fresh retail oysters were washed with sterilized water, and $5 \mathrm{~g}$ of oyster meat was blended with $45 \mathrm{ml}$ of TSB containing an additional $2.5 \% \mathrm{NaCl}$. The oyster sample was heated at $60^{\circ} \mathrm{C}$ for $10 \mathrm{~min}$ and was then filtered with cheesecloth. Samples of $10 \mathrm{ml}$ of homogenate were inoculated with $V$. parahaemolyticus at 9,300, 930, 93, 9.3, and 0 $\mathrm{CFU} / \mathrm{g}$. One milliliter of each homogenate was then mixed with $9 \mathrm{ml}$ of TSB containing an additional $2.5 \% \mathrm{NaCl}$ in a 50 -ml flask and incubated at $35^{\circ} \mathrm{C}$ for 0 , 3,6 , or $9 \mathrm{~h}$ in a shaker (YIHDER LM-570R, Taipei, Taiwan) at $50 \mathrm{rpm}$. After enrichment, the inoculated samples were stored at $-20^{\circ} \mathrm{C}$ until they were analyzed.

DNA extractions for PCR analysis. All pure culture DNAs were prepared with the mini-preparation of chromosomal DNA method described by Ausubel et al. (2). Bacterial chromosomal DNA was extracted by SDS-proteinase K lysis, followed by hexadecyltrimethyl ammonium bromide (CTAB) treatment, two phenol-chloroform-isoamyl alcohol extractions, and absolute ethanol precipitation. 
The purified DNA was then suspended in small volumes of TE buffer (10 mM Tris- $\mathrm{HCl}$ [pH 8], 1 mM EDTA).

$V$. parahaemolyticus DNAs to be used as PCR templates were extracted from oyster homogenates by three methods. For the first method, $0.5 \mathrm{ml}$ of oyster homogenate was heated at $100^{\circ} \mathrm{C}$ for $10 \mathrm{~min}$ (protocol I). The second method simply involved the addition of $50 \mu \mathrm{l}$ of $10 \%$ Triton X-100 (Riedel-deHaën) to $0.5 \mathrm{ml}$ of oyster homogenate and then heating of the sample at $100^{\circ} \mathrm{C}$ for $10 \mathrm{~min}$ (47) (protocol II). The third method involved the lysing of $0.5-\mathrm{ml}$ samples of the bacterial suspension with $1 \mathrm{mg}$ (final concentration) of lysozyme per $\mathrm{ml}$ (Sigma) at room temperature for $15 \mathrm{~min}$, followed by digestion with $200 \mu \mathrm{g}$ (final concentration) of proteinase $\mathrm{K}$ per $\mathrm{ml}$ (Boehringer Mannheim) at $60^{\circ} \mathrm{C}$ for $30 \mathrm{~min}$, followed by boiling for $10 \mathrm{~min}$ (29) (protocol III). All treated oyster samples were stored at $-20^{\circ} \mathrm{C}$ until they were analyzed. When PCR amplification was applied, the treated samples were undiluted or diluted 10-fold.

Procedure for analysis of food samples by PCR. Food samples were obtained from local retail shops and supermarkets. Twenty five grams of food samples was homogenized in a Stomacher 400 (Seward, London, England) with $225 \mathrm{ml}$ of 3\% $\mathrm{NaCl}$ for $60 \mathrm{~s}$. One milliliter of homogenate was mixed with $9 \mathrm{ml}$ of salt polymyxin broth (per liter containing $10.0 \mathrm{~g}$ of peptone, $3.0 \mathrm{~g}$ of yeast extract, $20.0 \mathrm{~g}$ of sodium chloride, and $250,000 \mathrm{U}$ of polymyxin $\mathrm{B}$ [pH 7.4]; Nissui, Tokyo, Japan) (SPB) and tested for the presence of $V$. parahaemolyticus by the classical culture method described below. Five milliliters of homogenate was added to 45 $\mathrm{ml}$ of SPB and incubated for $6 \mathrm{~h}$ at $35^{\circ} \mathrm{C}$. Afterwards, $1 \mathrm{ml}$ of enrichment broth was lysed as described in protocol III and then was subjected to PCR amplification both undiluted and diluted 10- or 100-fold.

Classical culture method. Isolation and enrichment steps were performed in accordance with procedures in the Bacteriological Analytical Manual (46). One loopful of enrichment broth was then plated onto thiosulfate citrate bile salts agar and incubated at $35^{\circ} \mathrm{C}$ overnight. Green colonies thought to be $V$. parahaemolyticus were further characterized by using the minimal number of biochemical tests described in the Bacteriological Analytical Manual (46). Further tests, including a motility test, ornithine decarboxylase production, and lactose and mannitol fermentation, were also carried out for identification of $V$. parahaemolyticus.

Nucleotide sequence accession number. The nucleotide sequence data presented in this paper will appear in the EMBL and GenBank nucleotide sequence databases under accession number L30116.

\section{RESULTS}

Nucleotide sequence of pR72H. The DNA nucleotide sequence of $\mathrm{pR} 72 \mathrm{H}$ isolated from $V$. parahaemolyticus 93 is shown in Fig. 1. The molecular $\mathrm{G}+\mathrm{C}$ content for the $711 \mathrm{bp}$ in a length of $\mathrm{pR} 72 \mathrm{H}$ is $39 \%$, compared with 46 to $47 \%$ for the chromosomes of $V$. parahaemolyticus. Neither potential translational start sites, possible open reading frames, nor the consensus Shine-Dalgarno sequence was found. The nucleotide sequence of $\mathrm{pR} 72 \mathrm{H}$ was analyzed for homology to the known sequences in the EMBL and GenBank databases with the GENALIGN program from IntelliGenetics. There was no significant homology of the $\mathrm{pR} 72 \mathrm{H}$ sequence to $V$. parahaemolyticus hemolysin genes $d v h, t d h, t r h$, or $t h ; V$. parahaemolyticus $5 \mathrm{~S}$ or $16 \mathrm{~S}$ rRNA; or $V$. parahaemolyticus insertion sequencelike elements.

Development of the PCR assay. Primer pair VP33-VP32 was designed on the basis of the nucleotide sequence of $\mathrm{pR} 72 \mathrm{H}$ determined in this study (Fig. 1). The nucleotide sequences of the primers and localizations on the $\mathrm{pR} 72 \mathrm{H}$ sequence are shown in Fig. 1. Primer pair VP33-VP32 was used to amplify target sequences in genomic DNA from five strains of $V$. parahaemolyticus and eight strains of other vibrios and other genera. An expected product with a length of $387 \mathrm{bp}$ was found from these five strains of $V$. parahaemolyticus, while nonspecific products were not found (Fig. 2A). Southern blot hybridization with an internal oligonucleotide DNA probe (VP35) showed that the 387-bp DNA fragments from $V$. parahaemolyticus could hybridize with the oligonucleotide probe that was derived from the sequence located between the two primers VP33 and VP32 (Fig. 2B).

Specificity of the PCR. To evaluate the specificity of the PCR assay, PCR amplification was performed with 124 strains of $V$. parahaemolyticus and 50 other bacterial strains with purified chromosomal DNA as a template. The PCR amplifica-

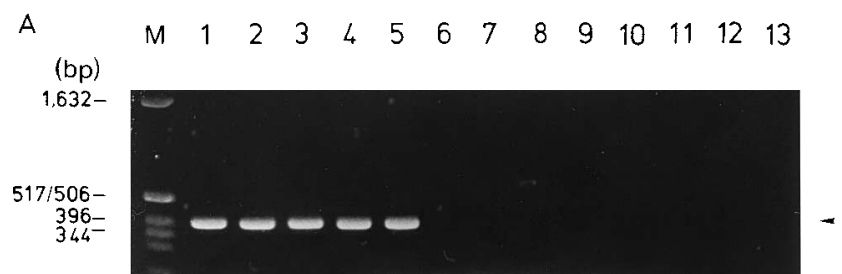

B

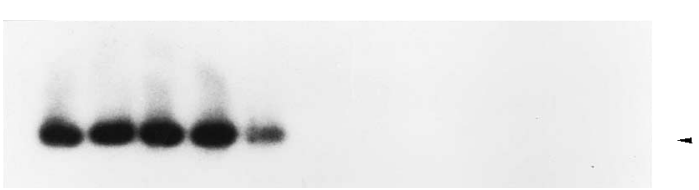

FIG. 2. Specific amplification of the 387-bp fragment (arrows) from the total DNA of $V$. parahaemolyticus and other genera. (A) Two percent agarose gel electrophoresis of PCR product. (B) Southern blot analysis of the product probed with ${ }^{32}$ P-labeled VP35. Lanes: M, molecular size marker pBR322/HinfI; 1 to $5, V$. parahaemolyticus strains $93, \mathrm{~A} 92,175,176$, and 178, respectively; 6 and 7, Vibrio alginolyticus ATCC 17749 and 179, respectively; 8, V. vulnificus ATCC 33147; 9, Vibrio campbellii ATCC 25920; 10, Vibrio costicola ATCC 33508; 11 , Staphylococcus aureus ATCC 65389; 12 and 13, E. coli IAM C-600 and A15, respectively.

tion with the VP33 and VP32 primers generated 387-bp-amplified DNA bands for all $V$. parahaemolyticus strains tested, while no amplification was apparent for non- $V$. parahaemolyticus bacterial strains. The ${ }^{32} \mathrm{P}$-labeled internal oligonucleotide probe VP35 showed positive hybridizations with the amplified DNA from the $V$. parahaemolyticus strains, and some of the dot blot hybridization results are shown in Fig. 3. These results indicate that the oligonucleotide primers VP33 and VP32, as well as the PCR procedure, were adequate for specific detection of $V$. parahaemolyticus. These results are also in agreement with our previous DNA hybridization results (28), which indicated that the reported nucleotide sequence of the insert of $V$. parahaemolyticus $93, \mathrm{pR} 72 \mathrm{H}$, is conserved in all $V$. parahaemolyticus strains.

Sensitivity of PCR. A dilution series of genomic DNA of $V$. parahaemolyticus 93 was prepared as described in Materials and Methods. Aliquots of each dilution were used as templates for PCR amplification with 25 or 35 cycles. Aliquots containing $2.6 \mathrm{pg}$ of genomic DNA could be detected successfully after

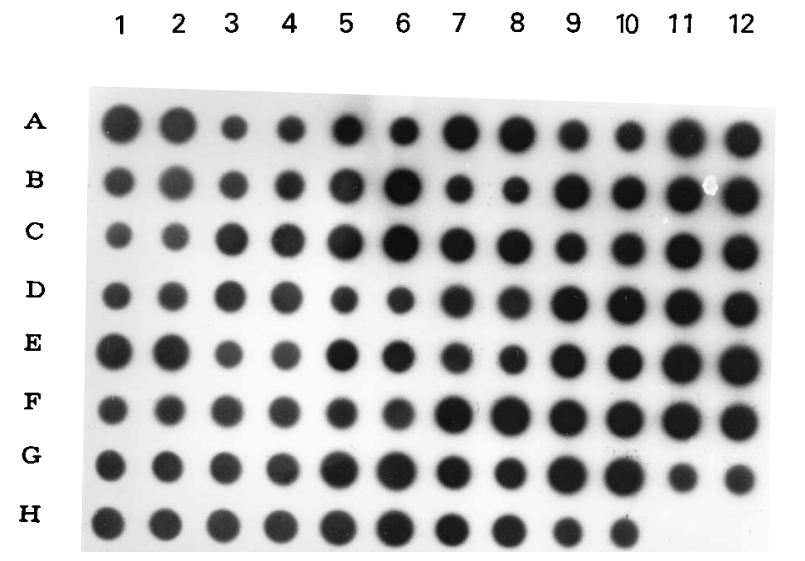

FIG. 3. Results of dot blot hybridization of $V$. parahaemolyticus with ${ }^{32} \mathrm{P}$ labeled VP35. Dots A1 and A2, V. parahaemolyticus 93 as a positive control; dots H11 and H12, salmon sperm DNA as a negative control. The other 92 dots represent 46 strains of $V$. parahaemolyticus (each strain is duplicated) as indicated in Table 1. 
A

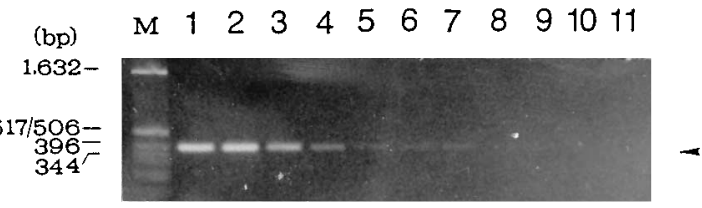

B

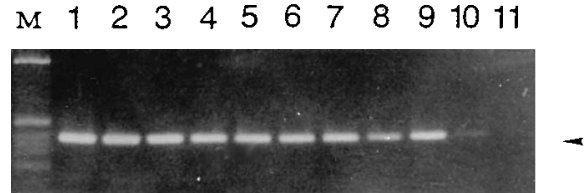

FIG. 4. Analysis of the limit of $V$. parahaemolyticus detection by PCR amplification with 25 (A) and 35 (B) cycles by agarose gel electrophoresis. Lane M, molecular size marker pBR322/HinfI. The amounts of DNA template in the initial PCR mixtures were as follows (by lane): 1, $2.6 \mu \mathrm{g} ; 2,260 \mathrm{ng} ; 3,26 \mathrm{ng} ; 4$, $2.6 \mathrm{ng} ; 5,260 \mathrm{pg} ; 6,26 \mathrm{pg} ; 7,2.6 \mathrm{pg} ; 8,260 \mathrm{fg} ; 9,26 \mathrm{fg} ; 10,2.6 \mathrm{fg}$; and 11, $0 \mathrm{fg}$.

amplification with 25 cycles, while the detection limit could be increased to $2.6 \mathrm{fg}$ once amplification with 35 cycles was performed (Fig. 4). Thus, 35 cycles of PCR were performed throughout the experiments in this study.

PCR sensitivity tests for $V$. parahaemolyticus seeded to oysters. When oyster samples were cultured in TSA-3\% $\mathrm{NaCl}$ for $0 \mathrm{~h}$, the initial sample inocula of 9.3 to $9.3 \times 10^{3} \mathrm{CFU}$ of $V$. parahaemolyticus 93 per g were always PCR negative. After $3 \mathrm{~h}$ of incubation, an initial inoculum of $9.3 \mathrm{CFU}$ of this $V$. parahaemolyticus strain per $\mathrm{g}$ was detected by PCR assay with DNA extracted according to protocol III (Fig. 5). Comparison of the three protocols of DNA extraction was performed, and protocol III provided the highest level of sensitivity for $V$. parahaemolyticus detection. After the culturing, the bacterial lysates subjected to PCR amplifications needed 10-fold dilution; falsenegative results were given without such dilution (Table 2).

Detection of $V$. parahaemolyticus by PCR in the presence of Escherichia coli. To investigate whether the presence of other bacteria with the target bacteria would inhibit the PCR, we used mixtures of $V$. parahaemolyticus and $E$. coli cultures as PCR templates to evaluate the sensitivity of this PCR protocol for detection of $V$. parahaemolyticus. Fresh, growing cultures of $V$. parahaemolyticus and E. coli cells were diluted separately and then mixed with each other to equal volumes. Five microliters of mixed-cell suspensions was lysed as described in protocol III and then was subjected to PCR amplification. As shown in Table 3, the sensitivity of PCR for the detection of $V$. parahaemolyticus for a pure culture of $V$. parahaemolyticus was $2 \times 10^{3}$ cells per ml ( 10 cells in $50 \mu \mathrm{l}$ of PCR mixture $)$. The PCR was inhibited when the number of $V$. parahaemolyticus cells increased to $2 \times 10^{10}$ cells in $1 \mathrm{ml}$ of mixed-cell suspension $\left(10^{8}\right.$ cells in $50 \mu$ l of PCR mixture). High levels $\left(10^{6}\right.$ to $10^{10} \mathrm{CFU} / \mathrm{ml}$ ) of $E$. coli cells did not affect the PCR-culture assay sensitivity and specificity. However, the presence of $10^{11}$ E. coli cells per ml of mixed-cell suspension $\left(10^{9}\right.$ cells in $50 \mu \mathrm{l}$ of PCR mixture) inhibited the PCR, as found from observation of ethidium bromide-stained agarose gel electrophoresis (Table 3).

Application of PCR for detection of $V$. parahaemolyticus in natural shellfish and fish samples. The PCR assay with enrichment culturing and the conventional culture method were used to examine 18 natural shellfish and fish samples for the presence of $V$. parahaemolyticus. From each sample, a $25-\mathrm{g}$ sample was subjected to enrichment culturing in SPB for $6 \mathrm{~h}$ and assayed by PCR. Because SPB is much more selective than

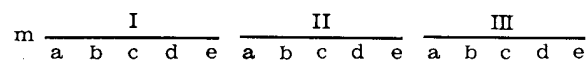

A

B

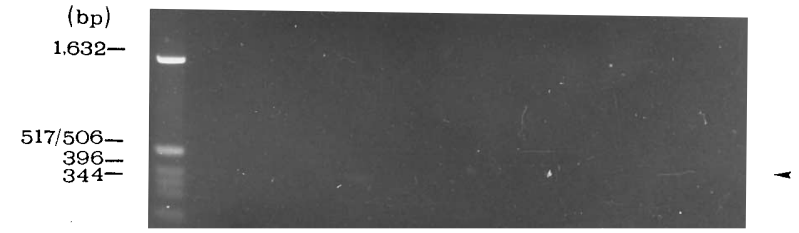

C
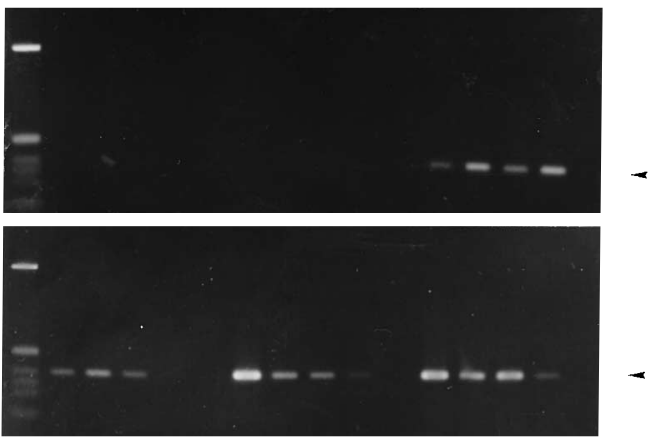

D

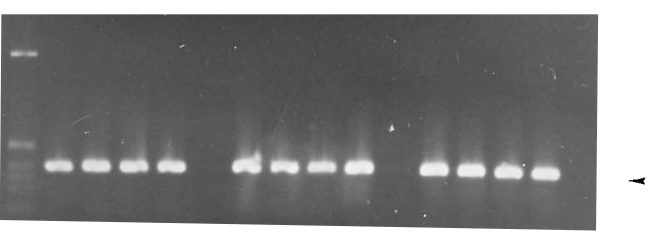

FIG. 5. Agarose gel electrophoresis of 10-fold-diluted amplification products obtained from oyster samples contaminated with serial 10-fold dilutions of $V$. parahaemolyticus. The oyster samples were enriched for 0 (A), 3 (B), 6 (C), or 9 (D) h, and then the DNAs were extracted from the enriched oyster homogenates by protocol I, II, or III. Lanes: m, molecular size marker pBR322/HinfI; a to e, PCR products of oyster homogenate lysates with initial contamination levels of V. parahaemolyticus 93 of $9300,930,93,9.3$, and $0 \mathrm{CFU} / \mathrm{g}$, respectively.

TSB-3\% NaCl broth for $V$. parahaemolyticus, we chose SPB as the enrichment broth for screening of $V$. parahaemolyticus in natural shellfish samples (unpublished data). Sixteen samples were found to be positive by the method involving both the SPB enrichment culture and PCR assay. $V$. parahaemolyticus was found to be present in 12 of these samples by the culture method (Table 4). All food samples considered to be naturally contaminated by $V$. parahaemolyticus with the conventional culture method were detected with the PCR culture assay as well.

\section{DISCUSSION}

In this report, we sequenced $\mathrm{pR} 72 \mathrm{H}$, a cloned DNA fragment of chromosome, from V. parahaemolyticus 93 (Fig. 1). On the basis of this sequence, we designed and established a PCR assay with enrichment culturing to detect $V$. parahaemolyticus in food samples. This PCR assay was found to be highly specific for $V$. parahaemolyticus, with the primers VP33 and VP32 yielding an amplified 387-bp DNA fragment unique to $V$. parahaemolyticus (Fig. 2). Moreover, it was possible to identify $V$. parahaemolyticus from food samples in only $10 \mathrm{~h}$ with this assay, including $6 \mathrm{~h}$ of enrichment, $3 \mathrm{~h}$ of PCR, and $1 \mathrm{~h}$ of agarose gel electrophoresis. The PCR assay we have described could reliably detect $2.6 \mathrm{fg}$ of purified Vibrio DNA amplified through 35 cycles (Fig. 4), which corresponds to approximately 1 cell. This level of sensitivity was higher than those reported by others: $400 \mathrm{fg}$ of cellular DNA by PCR amplification (43) and $28 \mathrm{fg}$ of DNA by a microtiter-based nonisotopic method 
TABLE 2. Effect of enrichment length and DNA preparation protocol on PCR detection limit

\begin{tabular}{|c|c|c|c|c|c|c|c|c|c|c|c|c|c|c|c|c|}
\hline \multirow{3}{*}{$\begin{array}{l}\text { Enrichment } \\
\text { duration } \\
\text { (h) }\end{array}$} & \multirow{3}{*}{$\begin{array}{c}\text { Fold PCR } \\
\text { dilution }\end{array}$} & \multicolumn{15}{|c|}{ Response to initial contamination tested (CFU/g) for protocols given ${ }^{a}$ : } \\
\hline & & \multicolumn{3}{|c|}{9,300} & \multicolumn{3}{|c|}{930} & \multicolumn{3}{|c|}{93} & \multicolumn{3}{|c|}{9.3} & \multicolumn{3}{|c|}{0} \\
\hline & & $\mathrm{I}$ & II & $\overline{\text { III }}$ & $\mathrm{I}$ & II & $\overline{\text { III }}$ & I & II & $\overline{\text { III }}$ & $\mathrm{I}$ & II & $\overline{\text { III }}$ & $\mathrm{I}$ & II & III \\
\hline \multirow[t]{2}{*}{0} & $10^{0}$ & & - & - & - & - & - & - & - & - & - & - & - & - & - & - \\
\hline & $10^{1}$ & - & - & - & - & - & - & - & - & - & - & - & - & - & - & - \\
\hline \multirow[t]{2}{*}{3} & $10^{0}$ & - & - & - & - & - & - & - & - & - & - & - & - & - & - & - \\
\hline & $10^{1}$ & - & - & + & - & - & + & - & - & + & - & - & + & - & - & - \\
\hline \multirow[t]{2}{*}{6} & $10^{\circ}$ & - & - & - & - & - & - & - & - & - & - & - & - & - & - & - \\
\hline & $10^{1}$ & + & + & + & + & + & + & + & + & + & - & + & + & - & - & - \\
\hline \multirow[t]{2}{*}{9} & $10^{\circ}$ & - & - & - & - & - & - & - & - & - & - & - & - & - & - & - \\
\hline & $10^{1}$ & + & + & + & + & + & + & + & + & + & + & + & + & - & - & - \\
\hline
\end{tabular}

${ }^{a}$ Three different protocols (I, II, and III) were used to extract DNAs from oyster homogenates as described in Materials and Methods. + , specific 387 -bp fragment found; -, specific 387-bp fragment not found.

for the detection of amplicons (42). By using crude cell extracts of $V$. parahaemolyticus prepared by proteinase $\mathrm{K}$ treatments, a 10 -CFU $\left(2 \times 10^{3} \mathrm{CFU} / \mathrm{ml}\right)$ level of detection of $V$. parahaemolyticus whole cells was found (Table 3 ).

The three methods used for template DNA preparation, protocols I, II, and III, were compared by PCR assay for the detection of artificially contaminated oysters seeded with various numbers of $V$. parahaemolyticus cells. The boiling method (protocols I and II) was simpler than the lysis method (protocol III) for the preparation of PCR templates. However, our results indicated that the lysis method was a more sensitive detection method for $V$. parahaemolyticus by PCR assay (Table 2 and Fig. 5). This result agreed with that of Makino et al. (32), who detected Bacillus anthracis DNA in animal samples and suggested using the lysis method to prepare samples. Therefore, the method of proteinase $\mathrm{K}$ treatment was used to prepare PCR templates throughout the subsequent experiments.

Wang et al. (47) recently reported that PCR assays could give false-negative results if more than $10^{5}$ or $10^{6} \mathrm{CFU}$ of target cells in a $25-\mu$ l PCR mixture was used for the assay. Niederhauser et al. (34) also reported that high concentrations of bacterial DNA could lead to inhibition of enzymatic amplification. Other researchers found that the sensitivity of PCR detection for target bacteria was reduced in mixed cultures with $E$. coli $(10,16)$, while Giesendorf et al. (15) found that high levels $\left(10^{6}\right.$ to $\left.10^{8} \mathrm{CFU} / \mathrm{g}\right)$ of other contaminating bacteria in chicken products did not affect the specificity of the PCRculture assay for detection of Campylobacter spp. In this study, we observed that the PCR products produced with $10^{7} \mathrm{CFU}$ (2 $\times 10^{9} \mathrm{CFU} / \mathrm{ml}$ ) of $V$. parahaemolyticus were less intense than those produced with $10^{6} \mathrm{CFU}\left(2 \times 10^{8} \mathrm{CFU} / \mathrm{ml}\right)$ of $V$. parahaemolyticus, regardless of the absence or presence of different numbers of $E$. coli cells (data not shown). The PCR products were not observed in ethidium bromide-stained agarose gel electrophoresis when the number of $V$. parahaemolyticus cells in a $50-\mu \mathrm{l}$ PCR mixture increased to $10^{8} \mathrm{CFU}\left(2 \times 10^{10}\right.$ $\mathrm{CFU} / \mathrm{ml}$ ) (Table 3 ). This result suggested that when the number of target cells of $V$. parahaemolyticus in the PCR mixtures was greater than $10^{6} \mathrm{CFU}$, there was a negative effect on the reaction. As shown in Table 3 , the presence of $10^{9} \mathrm{E}$. coli cells in the PCR mixtures $\left(2 \times 10^{11} \mathrm{CFU} / \mathrm{ml}\right)$ completely inhibited amplification of target DNA. However, the detection limit of $V$. parahaemolyticus was not reduced when $10^{4}$ to $10^{8} \mathrm{E}$. coli cells were present in the PCR mixtures.

Analysis of artificially contaminated samples indicated that protocol III with only $3 \mathrm{~h}$ of enrichment enabled reliable detection of a small number of cells (Table 2). However, it has been reported that $V$. parahaemolyticus can be injured or inactivated by environmental challenges $(4,14,27,37)$. Niederhauser et al. (34) also proposed that, in contrast to fully viable food-borne pathogens seeded in food samples, food-borne pathogens present in natural food samples have reduced viability. Therefore, when the PCR assay was applied to the naturally contaminated food samples, we extended the enrichment length to $6 \mathrm{~h}$ for recovery of stressed cells. In the experiments with the application of PCR-culture assay in nat-

TABLE 3. Detection of $V$. parahaemolyticus by PCR in the presence of E. coli

\begin{tabular}{|c|c|c|c|c|c|c|c|}
\hline \multirow{2}{*}{$\begin{array}{l}\text { No. of } V \text {. parahaemolyticus } \\
\text { cells/ml of mixed } \\
\text { suspension }\end{array}$} & \multicolumn{7}{|c|}{ Detection with no. of $E$. coli cells $/ \mathrm{ml}$ of mixed suspension ${ }^{a}$} \\
\hline & $2 \times 10^{11}$ & $2 \times 10^{10}$ & $2 \times 10^{9}$ & $2 \times 10^{8}$ & $2 \times 10^{7}$ & $2 \times 10^{6}$ & $\overline{0}$ \\
\hline $2 \times 10^{10}$ & - & - & - & - & - & - & - \\
\hline $2 \times 10^{9}$ & - & + & + & + & + & + & + \\
\hline $2 \times 10^{8}$ & - & + & + & + & + & + & + \\
\hline $2 \times 10^{7}$ & - & + & + & + & + & + & + \\
\hline $2 \times 10^{6}$ & - & + & + & + & + & + & + \\
\hline $2 \times 10^{5}$ & - & + & + & + & + & + & + \\
\hline $2 \times 10^{4}$ & - & + & + & + & + & + & + \\
\hline $2 \times 10^{3}$ & - & + & + & + & + & + & + \\
\hline $2 \times 10^{2}$ & - & - & - & - & - & - & - \\
\hline 0 & - & - & - & - & - & - & - \\
\hline
\end{tabular}

${ }^{a}+$, specific 387-bp fragment found by gel electrophoresis; - , specific 387-bp fragment not found. 
TABLE 4. PCR and culture methods for detection of $V$. parahaemolyticus in naturally contaminated food samples

\begin{tabular}{lcc}
\hline \multirow{2}{*}{ Food sample } & \multicolumn{2}{c}{ No. of samples positive/no. tested by: } \\
\cline { 2 - 3 } & $\begin{array}{c}\text { PCR with SPB } \\
\text { enrichment }\end{array}$ & $\begin{array}{r}\text { Culture } \\
\text { method }\end{array}$ \\
\hline Oyster & $2 / 3$ & $2 / 3$ \\
Shrimp & $2 / 2$ & $2 / 2$ \\
Clam & $4 / 5$ & $4 / 5$ \\
Fish & $3 / 3$ & $0 / 3$ \\
Squid & $5 / 5$ & $4 / 5$ \\
Total & $16 / 18$ & $12 / 18$ \\
\hline
\end{tabular}

ural shellfish and fish samples, three fish samples and one squid sample were positive by the PCR assay for V. parahaemolyticus, while they were negative with the culture method (Table 4). We conclude that these food samples were contaminated with $V$. parahaemolyticus which was not detectable under the conditions tested. Brauns et al. (4) have demonstrated that PCR is potentially able to detect the presence of viable but nonculturable Vibrio vulnificus cells.

Direct detection of pathogens in food samples by PCR presents some technical problems, as reported by several authors $(1,10,13,16,17,24,34,45,47,49,50)$. It is concluded that components of food, enrichment media, or a high concentration of DNA may lead to inhibition of the PCR. However, these difficulties could be overcome by performing nucleic acid extraction or by diluting the lysate before PCR amplification. Recently, a new detection system, the magnetic immuno-PCR assay, has been developed to detect pathogens in food. This method separates target cells from food samples by using magnetic beads coated with specific monoclonal antibodies $(11,12$, 26). However, this method requires antibodies specific to various serogroups of the target pathogen (26). In this study, the proposed PCR-culture assay could increase the number of target cells and dilute out non-Vibrio DNA and other inhibitors of PCR which may exist in food samples. It also ensures that only $V$. parahaemolyticus DNA obtained from viable cells is detected.

Because $V$. parahaemolyticus represents a marine bacterium that is often found in marine and estuarine water samples and shellfish $(3,9,48)$, surveillance of contamination in food samples, in shelf stock of retail seafood markets, and in seafood plants is important $(6,9)$. Although the multiplication of environmental strains of $V$. parahaemolyticus in oysters does not necessarily indicate a human health risk, the PCR-culture assay with VP33 and VP32 primers established in this study can facilitate the monitoring of bacterial contamination by detecting the 387-bp DNA fragment in seafood samples and can reduce any potential health risk. A further study to design both a colorimetric method for detection of PCR-amplified DNA sequences in solid phase and an internal standard for the PCR assay is in progress.

\section{ACKNOWLEDGMENTS}

This work was supported by grant FS82-12 from the Department of Health, Executive Yuan, and was supported in part by the National Science Council (NSC81-0409-B-002-69), Taipei, Taiwan, Republic of China.

\section{REFERENCES}

1. Atmar, R. L., T. G. Metcalf, F. H. Neill, and M. K. Estes. 1993. Detection of enteric viruses in oysters by using the polymerase chain reaction. Appl. Environ. Microbiol. 59:631-635.
2. Ausubel, F. M., R. Brent, R. E. Kingston, D. D. Moore, J. G. Seidman, J. A. Smith, and K. Struhl. 1987. Current protocols in molecular biology. John Wiley, New York.

3. Bartley, C. H., and L. W. Slanetz. 1971. Occurrence of Vibrio parahaemolyticus in estuarine waters and oysters of New Hampshire. Appl. Microbiol. 21:965-966.

4. Brauns, L. A., M. C. Hudson, and J. D. Oliver. 1991. Use of the polymerase chain reaction in detection of culturable and nonculturable Vibrio vulnificus cells. Appl. Environ. Microbiol. 57:2651-2655.

5. Chiou, A., L. H. Chen, and S. K. Chen. 1991. Foodborne illness in Taiwan, 1981-1989. Food Aust. 43:70-71.

6. Cook, D. W., and A. D. Ruple. 1989. Indicator bacteria and Vibrionaceae multiplication in post-harvest shellstock oysters. J. Food Prot. 52:343-349.

7. Dai, J.-H., Y.-S. Lee, and H.-C. Wong. 1992. Effects of iron limitation on production of a siderophore, outer membrane proteins, and hemolysin and on hydrophobicity, cell adherence, and lethality for mice of Vibrio parahaemolyticus. Infect. Immun. 60:2952-2956.

8. DePaola, A., L. H. Hopkins, and R. M. McPhearson. 1988. Evaluation of four methods for enumeration of Vibrio parahaemolyticus. Appl. Environ. Microbiol. 54:617-618.

9. DePaola, A., L. H. Hopkins, J. T. Peeler, B. Wentz, and R. M. McPhearson. 1990. Incidence of Vibrio parahaemolyticus in U.S. coastal waters and oysters. Appl. Environ. Microbiol. 56:2299-2302.

10. Fach, P., D. Hauser, J. P. Guillou, and M. R. Popoff. 1993. Polymerase chain reaction for the rapid identification of Clostridium botulinum type A strains and detection in food samples. J. Appl. Bacteriol. 75:234-239.

11. Fluit, A. C., R. Torensma, M. J. C. Visser, C. J. M. Aarsman, M. J. J. G. Poppelier, B. H. I. Keller, P. Klapwijk, and J. Verhoef. 1993. Detection of Listeria monocytogenes in cheese with the magnetic immuno-polymerase chain reaction assay. Appl. Environ. Microbiol. 59:1289-1293.

12. Fluit, A. C., M. N. Widjojoatmodjo, A. T. A. Box, R. Torensma, and J. Verhoef. 1993. Rapid detection of salmonellae in poultry with the magnetic immuno-polymerase chain reaction assay. Appl. Environ. Microbiol. 59: 1342-1346.

13. Furrer, B., U. Candrian, C. Hoefelein, and J. Luethy. 1991. Detection and identification of Listeria monocytogenes in cooked sausage products and in milk by in vitro amplification of haemolysin gene fragments. J. Appl. Bacteriol. 70:372-379.

14. Gannon, V. P. J., R. K. King, J. Y. Kim, and E. J. G. Thomas. 1992. Rapid and sensitive method for detection of Shiga-like toxin-producing Escherichia coli in ground beef using the polymerase chain reaction. Appl. Environ. Microbiol. 58:3809-3815.

15. Giesendorf, B. A. J., W. G. V. Quint, M. H. C. Henkens, H. Stegeman, F. A. Huf, and H. G. M. Niesters. 1992. Rapid and sensitive detection of Campylobacter spp. in chicken products by using the polymerase chain reaction. Appl. Environ. Microbiol. 58:3804-3808.

16. Grant, K. A., J. H. Dickinson, M. D. Collins, and R. G. Kroll. 1992. Rapid identification of Aerococcus viridans using the polymerase chain reaction and an oligonucleotide probe. FEMS Microbiol. Lett. 95:63-68.

17. Hill, W. E., S. P. Keasler, M. W. Trucksess, P. Feng, C. A. Kaysner, and K. A. Lampel. 1991. Polymerase chain reaction identification of Vibrio vulnificus in artificially contaminated oysters. Appl. Environ. Microbiol. 57:707-711.

18. Honda, T., M. A. Abad-Lapuebla, Y. Ni, K. Yamamoto, and T. Miwatani. 1991. Characterization of a new thermostable direct haemolysin produced by a Kanagawa-phenomenon-negative clinical isolate of Vibrio parahaemolyticus. J. Gen. Microbiol. 137:253-259.

19. Honda, T., M. Shimizu, Y. Takeda, and T. Miwatani. 1976. Isolation of a factor causing morphological changes of Chinese hamster ovary cells from the culture filtrate of Vibrio parahaemolyticus. Infect. Immun. 14:1028-1033.

20. Honda, T., S. Taga, T. Takeda, M. A. Hasibuan, Y. Takeda, and T. Miwatani. 1976. Identification of lethal toxin with the thermostable direct hemolysin produced by Vibrio parahaemolyticus, and some physicochemical properties of the purified toxin. Infect. Immun. 13:133-139.

21. Hondo, S., I. Goto, I. Minematsu, N. Ikeda, N. Asano, M. Ishibashi, Y. Kinoshita, N. Nishibuchi, T. Honda, and T. Miwatani. 1987. Gastroenteritis due to Kanagawa negative Vibrio parahaemolyticus. Lancet i:331-332.

22. Janda, J. M., C. Powers, R. G. Bryant, and S. L. Abbott. 1988. Current perspectives on the epidemiology and pathogenesis of clinically significant Vibrio spp. Clin. Microbiol. Rev. 1:245-267.

23. Johnson, D. E., L. Weinberg, J. Ciarkowski, P. West, and R. R. Colwell 1984 Wound infection caused by Kanagawa-negative Vibrio parahaemolyticus. J. Clin. Microbiol. 20:811-812.

24. Jones, D. D., R. Law, and A. K. Bej. 1993. Detection of Salmonella spp. in oysters using polymerase chain reactions (PCR) and gene probes. J. Food Sci. 58:1191-1197.

25. Joseph, S. W., R. R. Colwell, and J. B. Kaper. 1982. Vibrio parahaemolyticus and related halophilic vibrios. Crit. Rev. Microbiol. 10:77-124.

26. Kapperud, G., T. Vardund, E. Skjerve, E. Hornes, and T. E. Michaelsen. 1993. Detection of pathogenic Yersinia enterocolitica in foods and water by immunomagnetic separation, nested polymerase chain reactions, and colorimetric detection of amplified DNA. Appl. Environ. Microbiol. 59:29382944. 
27. Kelly, M. T., and E. M. D. Stroh. 1988. Temporal relationship of Vibrio parahaemolyticus in patients and the environment. J. Clin. Microbiol. 26: 1754-1756.

28. Lee, C. Y., C. H. Chen, and Y. W. Chou. Characterization of a cloned pR72H probe for Vibrio parahaemolyticus detection and development of a nonisotopic colony hybridization assay. Microbiol. Immunol., in press.

29. Lee, C. Y., and S. F. Pan. 1993. Rapid and specific detection of the thermostable direct haemolysin gene in Vibrio parahaemolyticus by the polymerase chain reaction. J. Gen. Microbiol. 139:3225-3231.

30. Lee, C. Y., S. F. Pan, Y. S. Lee, and C. L. Lee. 1994. Detection and identification of Vibrio parahaemolyticus in fecal samples of outbreak patients by in vitro amplification of thermostable direct haemolysin gene fragment. J. Chin. Agric. Chem. Soc. 32:103-112.

31. Li, M., and H. P. Schweizer. 1993. Resolution of common DNA sequencing ambiguities of GC-rich DNA templates by terminal deoxynucleotidyl transferase without dGTP analogues. Focus 15:19-20.

32. Makino, S.-I., Y. Iinuma-Okada, T. Maruyama, T. Ezaki, C. Sasakawa, and M. Yoshikawa. 1993. Direct detection of Bacillus anthracis DNA in animals by polymerase chain reaction. J. Clin. Microbiol. 31:547-551.

33. Miyamoto, Y., T. Kato, Y. Obara, S. Akiyama, K. Takizawa, and S. Yamai. 1969. In vitro hemolytic characteristic of Vibrio parahaemolyticus: its close correlation with human pathogenicity. J. Bacteriol. 100:1147-1149.

34. Niederhauser, C., U. Candrian, C. Höfelein, M. Jermini, H.-P. Bühler, and J. Lüthy. 1992. Use of polymerase chain reaction for detection of Listeria monocytogenes in food. Appl. Environ. Microbiol. 58:1564-1568.

35. Nishibuchi, M., T. Taniguchi, T. Misawa, V. Khaeomanee-Iam, T. Honda, and T. Miwatani. 1989. Cloning and nucleotide sequence of the gene (trh) encoding the hemolysin related to the thermostable direct hemolysin of Vibrio parahaemolyticus. Infect. Immun. 57:2691-2697.

36. Reed, K. C., and D. A. Mann. 1985. Rapid transfer of DNA from agarose gels to nylon membranes. Nucleic Acids Res. 13:7207-7221.

37. Roszak, D. B., and R. R. Colwell. 1987. Survival strategies of bacteria in the natural environment. Microbiol. Rev. 51:365-379.

38. Sakazaki, R. 1979. Vibrio infections, p. 173-209. In H. Reimann and F. L. Bryan (ed.), Food borne infections and intoxications, 2nd ed. Academic Press, Inc., New York.

39. Sambrook, J., E. F. Fritsch, and T. Maniatis. 1989. Molecular cloning: a laboratory manual, 2nd ed. Cold Spring Harbor Laboratory Press, Cold Spring Harbor, N.Y.

40. Sanger, F., S. Nicklen, and A. R. Coulson. 1977. DNA sequencing with chain-terminating inhibitors. Proc. Natl. Acad. Sci. USA 74:5463-5467.
41. Sarkar, B. L., R. Kumar, S. P. De, and S. C. Pal. 1987. Hemolytic activity of and lethal toxin production by environmental strains of Vibrio parahaemolyticus. Appl. Environ. Microbiol. 53:2696-2698.

42. Tada, J., T. Ohashi, N. Nishimura, H. Ozaki, S. Fukishima, J. Takano, M. Nishibuchi, and Y. Takeda. 1992. Non-isotopic microtitre plate-based assay for detecting products of polymerase chain reaction amplification: application to detection of the $t d h$ gene of Vibrio parahaemolyticus. Mol. Cell. Probes 6:489-494.

43. Tada, J., T. Ohashi, N. Nishimura, Y. Shirasaki, H. Ozaki, S. Fukishima, J. Takano, M. Nishibuchi, and Y. Takeda. 1992. Detection of the thermostable direct hemolysin gene $(t d h)$ and the thermostable direct hemolysin-related hemolysin gene (trh) of Vibrio parahaemolyticus by polymerase chain reaction. Mol. Cell. Probes 6:477-487.

44. Takeda, Y. 1983. Thermostable direct hemolysin of Vibrio parahaemolyticus Pharmacol. Ther. 19:123-146.

45. Thomas, E. J. G., R. K. King, J. Burchak, and V. P. J. Gannon. 1991 Sensitive and specific detection of Listeria monocytogenes in milk and ground beef with the polymerase chain reaction. Appl. Environ. Microbiol. 57:25762580 .

46. Twedt, R. M., and G. N. Stelma, Jr. 1987. Bacteriological analytical manual, 6th ed., supplement, p. 12.01-12.10. Food and Drug Administration, Washington, D.C.

47. Wang, R.-F., W.-W. Cao, and M. G. Johnson. 1992. 16S rRNA-based probes and polymerase chain reaction method to detect Listeria monocytogenes cells added to foods. Appl. Environ. Microbiol. 58:2827-2831.

48. Watkins, W. D., and V. J. Cabelli. 1985. Effect of fecal pollution on Vibrio parahaemolyticus densities in an estuarine environment. Appl. Environ. Microbiol. 49:1307-1313.

49. Wernars, K., E. Delfgou, P. S. Soentoro, and S. Notermans. 1991. Successful approach for detection of low numbers of enterotoxigenic Escherichia coli in minced meat by using the polymerase chain reaction. Appl. Environ. Microbiol. 57:1914-1919.

50. Wernars, K., C. J. Heuvelman, T. Chakraborty, and S. H. W. Notermans. 1991. Use of the polymerase chain reaction for direct detection of Listeria monocytogenes in soft cheese. J. Appl. Bacteriol. 70:121-126.

51. Wilbur, W. J., and D. J. Lipman. 1983. Rapid similarity searches of nucleic acid and protein data banks. Proc. Natl. Acad. Sci. USA 80:726-730.

52. Yoh, M., T. Miwatani, and T. Honda. 1992. Comparison of Vibrio parahae molyticus hemolysin (VP-TRH) produced by environmental and clinical isolates. FEMS Microbiol. Lett. 92:157-162. 